<論 文 $>$

\title{
二次処理水のオゾン処理による 反応生成物の同定と定量
}

\author{
Identification and Quantitification of Products Resulting \\ from the Ozonation of Secondary Effluent

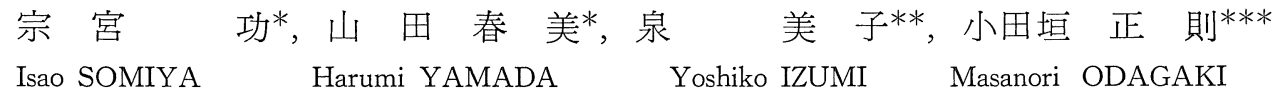

\begin{abstract}
Some batch ozonation experiments on the secondary effluents. The identification of intermediates and end products resulting from the ozonation was studied, setting the reaction time and the ozone concentrations applied as reaction parameters. The feed gas to the reactor had ozone concentration of $9.6-59.5 \mathrm{mg} / l$.

Trace amounts of formaldehyde, acetaldehyde, proponic aldehyde, methyglyoxal, glyoxylic acid and pyruvic acid were detected by gas chlomatography and colorimetry for 2, 4-dinitrophenylhydrazones. Formaldehyde was a common product resulting from the ozonation of many organic compounds in the early reaction time. But, this was finally oxidized to carbon dioxide by the prolonged reaction time at a faster rate. Methylglyoxal and pyruvic acid were also oxidized to pyruvic acid and acetic acid, respectively. But, the decomposition rate of pyruvic acid is not so fast as formaldehyde's.

Acetic acid, formic acid and propionic acid were also detected by gas chromatography for their benzyl esters. The latter two were present in trace amounts. The quantity of acetic acid increased with the reaction time increment.

During the course of the reaction, $1 / 6-1 / 5$ of total COD can be accounted for by the summations of each TOD on formaldehyde, methylglyoxal, pyruvic acid and acetic acid produced by the ozonation of secondary effluents.
\end{abstract}

\section{1. はじめに}

化学処理による反応生成物についての研究は, 浄水工 程の塩素処理過程でクロロホルム等の有機ハロゲン化合 物が生成される事実が発見されて以来関心が寄せられて きた。

オゾン処理は古くから塩素処理と並んで殺菌処理に使 われて抏り、オゾンは水中で分解して酸素に変るため塩 素の様な過剰添加による二次污染の心配がなく，また水 中の溶存酸素が増大する好ましい二次効果が得られるな
どの利点がある。

有機塩素化合物の生成で塩素処理の再検討が必要であ る現在，オゾン処理による反応生成物についても十分な 知見を得ることが急務であると思われる。

一般的にオゾンは有機物と反応してオゾニドをつく

り、オゾニドは分解してアルデヒド，ケトンなどのカル ボニル化合物やカルボン酸になる。Gould ら゙はフェ， ールのオゾン酸化による生成物としてグリオキシル酸,

*京都大学工学部衛生工学教室 ⿶604 京都市左京区吉田本町 Department of Sanitary Engineering, Faculty of Engineering, Kyoto University, Yoshida-Honmachi, Sakyo-ku, Kyoto 606

**京都水道設計事務所 ⿶604 京都市中京区鳥丸通三条東入ル, 京友三条ビル Kyoto Suido Sekkei Office, Karasuma-sanjo, Nakagyo-ku, Kyoto 604

***大阪府 荎540 大阪市東区大手前之町 Osaka Prefecture, Otemaenocho, Higashi-ku, Osaka 540

Vol. 2 No. 3 (1979) 
グリオキザール，シュウ酸の挙動を報告した。Powell P.K.KuO ら ${ }^{2)}$ は 2-プロパノール, 酢酸, シュウ酸をオ ゾン処理，拉よび紫外線照射を併用したオゾン処理を行 なった結果, アセトン, 酢酸, シュウ酸, グリオキシル 酸の生成, 酢酸, シュウ酸の分解を確認した。また筆者 ら2) は各種の有機物のオゾン処理によりホルムアルデヒ ドの生成拉よび分解が扣こることを報告した。これらの 報告をみてもオゾン処理生成物は主としてカルボニル化 合物やカルボン酸であるが，まだまだ系統的な把握はな されていない。

ところで、オゾン処理生成物であるカルボニル化合物 やカルボン酸を “有機塩素化合物一 ECD 検出器による ガスクロマトグラフィー”のよらにオールマイティな分 解機器で分析機器で分析することは現在の分析技術で は，まだ一般化されていない。

本研究は，2,4-ジニトロフェニルヒドラゾン化による カルボニル化合物拉よびベンジルェステル化によるカル ボン酸の定量法の検討を行ない，2次処理水のオゾン処 理に拈いて，送入オゾン濃度，処理時間等により，ぞの よらな反応生成物が，ぞの程度生成してくるかを実験的 に検討したものである。

\section{2. 実 験 方 法}

\section{1 試料}

京都市 $\mathrm{T}$ 下水処理の最終沈殿池沈後水 (2 次処理水) を東洋紙No.5 Cでろ過したものを試料とした。その試料 の性状は $\mathrm{COD}_{(\mathrm{Cr})} 39.7 \sim 45.2 \mathrm{mg} / l$, TOC9. $0 \sim 16.8 \mathrm{mg}$ $/ l, \mathrm{pH} 7.45 \sim 8.09$, フミン酸1.3〜 7.2mg/l であった。

\section{2 オゾン処理方法}

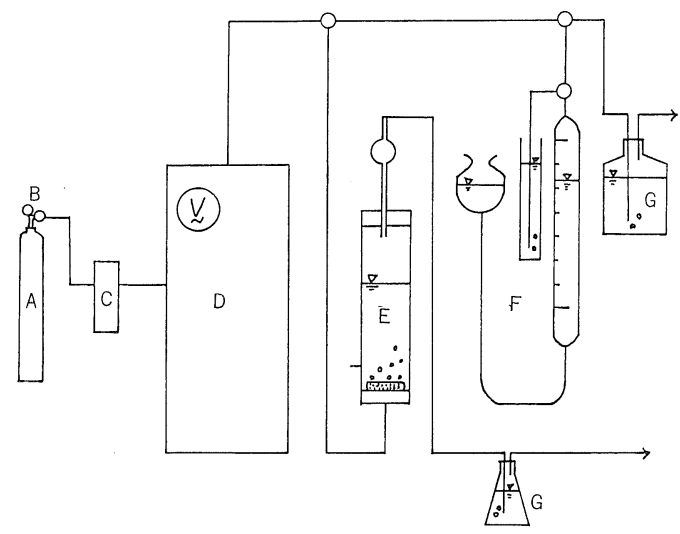

Fig. 1 A flow sheet of ozone oxidation apparatus A; Oxygen bomb, B; Pressure gauge, C; Flow meter, D; Ozone generator, E; Reaction vessel, F; Ozone concentration measurement apparatus, G; Trap (2\% KI Solution)
オゾン処理はFig. 1 に示す半バッチ式処理装置を用い た。オゾン発生装置は日本オゾン社製0-10-4型で, 酸素 源として市販の酸素ボンベを用いた。処理条件は水温20 ${ }^{\circ} \mathrm{C}$, 流量 $2 l / \mathrm{min}$, 送入オゾン濃度 $9.6 \sim 59.5 \mathrm{mg} / l$ であ った。処理に供するサンプル量は $1 l$ として，処理時間 $1 ， 2 ， 5 ， 10 ， 20 ， 60 ， 80$ 分ごとバッチ式で行なった。 処理後ただちに空気ばつ気を行ない，残留オン゙ンを除去 した。

\section{3 測定項目亡分析法}

オゾン処理水を $0.45 \mu$ メブランフィルターでろ過し たろ液について, $\mathrm{COD}_{(\mathrm{Cr})}$ (Standard Methods),カルボ= ル化合物，低級脂肪酸を分析した。ガスクロマトグラフ 分析には柳本 G-80型-FID を，吸光度測 定には島津製 SP 50型を用いた。

\section{4 カルボニル化合物の同定}

\section{4 .1 原理}

カルボニル化合物は2, 4-dinitrophenylhydrazine（以下 2,4-DNRと略す）と反応して2,4-dinitrophenylhydrazone (以下 $2,4-\mathrm{DNPH}$ と略す) を生成する。その反応を以下 に示す.

(1) アルデヒド，ケトン

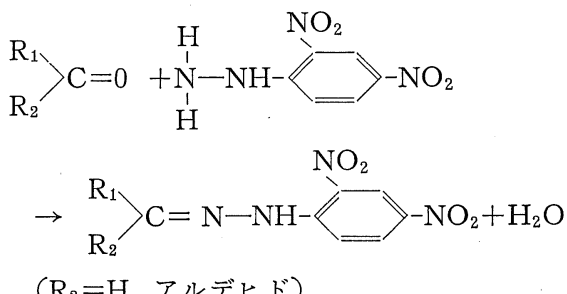

(2) オキソ酸

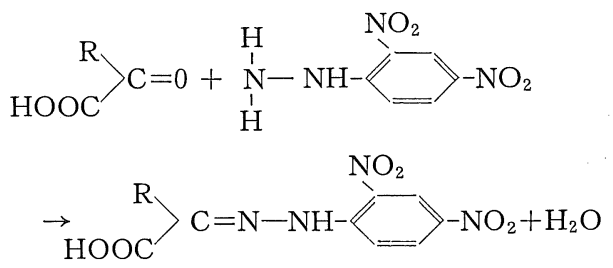

（3） ジガルボル化合 $\bigcirc$<smiles>[R]C(=O)C([R])=O</smiles> 
ここで(1)のアルデヒド，ケトンは直接ガスクロマト グラフィーで検出できる。（2）のオキソ酸は酸基をメチ ルエステル化すればガスクロマトグラフィーで検出でき る。（3）のジカルボニル化合物はアルカリ溶液で紫色を 呈する。

\subsubsection{2,4-DNPH 調製法}

試料 $100 \mathrm{~m} l$ に対して，0.1\%2,4-DNP $2 \mathrm{NHCl}$ 溶液 $40 \mathrm{ml}$ の割合で加光混合し，一昼夜放置して 2,4-DNPH にす る。

\section{4 .3 溶 媒}

カルボニル化合物の2,4-DNPHを抽出する溶媒として 酢酸エチル，キシレン，クロロホルムが考觉られる。こ の中で2,4-DNPHの溶解度は酷酸エチル媒体中ですぐれ ていたが，酢酸エチルは2,4-DNPと反応して N-acetyl-

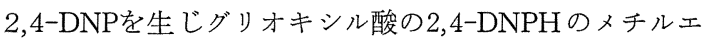
ステルと同じ保持時間を示すため適当でない4。キシレ ンとクロロホルルを用いて $1 \sim 5 \mathrm{mg} / l$ の既知の濃度( ウ化水銀カリウム滴定法による5) のホルムアルデヒド 溶液から調製した2,4-DNPH を抽出し，後述の条件で ガスクロマトグラフィーに注意した。別に作った検量線 によって求めた抽出溶媒中の濃度 $(Y \mathrm{mg} / l)$ と原サンプ ルのホルムアルデヒド濃度 $(X \mathrm{mg} / l)$ の間に次式の回帰 式が得られた.
Table 1 Recovery of formaldehyde (The concentration of formaldehyde: $1.07 \mathrm{mg} / l$ )

\begin{tabular}{l|c|c}
\hline \multicolumn{1}{c|}{ Solvent } & $\begin{array}{c}\text { Chloroform } \\
(n=9)\end{array}$ & $\begin{array}{c}\text { Xylene } \\
(n=7)\end{array}$ \\
\hline mean concentration $(\mathrm{mg} / l)$ & 1.01 & 0.92 \\
standard deviation & 0.106 & 0.143 \\
standard error & 0.035 & 0.054 \\
recovery (\%) & 94.4 & 85.8 \\
\hline
\end{tabular}

$$
\begin{aligned}
& \text { キシレン }: Y=0.817 X+0.163 \\
& \text { クロロホルム: } Y=0.572 X+0.448
\end{aligned}
$$

$$
(X: 1 \sim 5)
$$

これよりホルムアルデヒドの濃度が $1 \sim 5 \mathrm{mg} / l$ の間 ではキシレンの方が高い回収率を示した。しかし次の 3 点によりクロロホルムを使用することにした.

(1)キシレンはガスクロマトグラフィーの燃焼部でスス を多く発生し, 機器の污染が激しい.

(2)本実験の測定範囲は濃縮操作を行なってもホルムア ルデヒド濃度 $1 \mathrm{mg} / l$ 程度である。Table 1 はホルムア ルデヒド濃度 $1 \mathrm{mg} / l$ に拈けるクロロホルムとキシレン の回収率を表わしている。この濃度ではクロロホルムの 方が回収率は高い。

(3)後述のジアゾメタンによるメチルェステル化の際

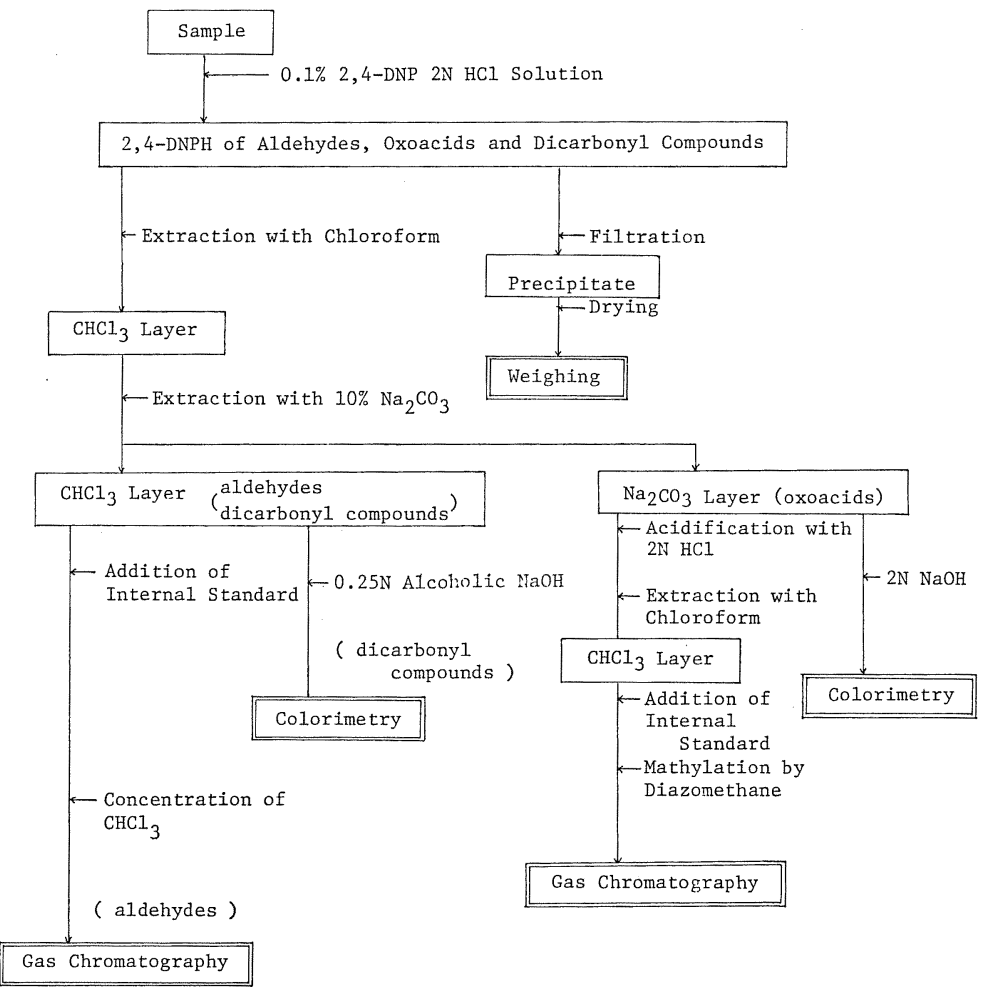

Fig. 2 Procedure for analysis of carbonyl compounds 
にクロロホルムは溶媒として使用可能であった

\section{4 .4 分析法}

2,4-DNPH の抽出, 分離, 科量, ガスクロマトグラ フィー拉よび比色による同定はFig. 2 に示すフローに従 って行なった。ここで用いた抽出法は主に清水ら ${ }^{6)}$ の方 法を参考にしたものである。

(1) 秤量 法

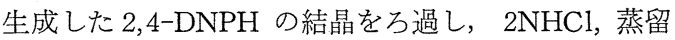
水の順で十分に洗浄, 真空デシケーターで乾燥後科量を 行なった。誤差はサンプル $200 \mathrm{ml}$ で $1.5 \mathrm{mg} / l$ であっ た。標準物質の 2,4-DNPH む同様に調製した。

(2) ガスクロマトグラフィー

2,4-DNPH 化したサンプルをクロロホルムで抽出し， 水洗後10\%炭酸ナトリウム溶液を加え, アルデヒド，ケ トンの2,4-DNPHを含む中性クロロホルム層と，オキソ 酸の2,4-DNPHを含むアルカリ層に分離した。とりだし たクロロホルム層に内部標準物質としてアンスラセンを 適量加光，ロータリーエバポレーターにより $2 \sim 3 \mathrm{mlk}$ 濃縮した。この濃縮操作はクロロホルムがガスクロマド グラフィーの燃燒部の電極を腐蝕するため注入量を $2 \mu$ 以下に特さ党るためである。この操作で $0.05 \mathrm{mg} / l$ まで のホルムアルデヒドが検出できた。さらに検出限界をあ げるにはサンプル量の増加, 濃縮倍率を高めることが必 要であると考えられる。な拉，一度蒸発乾固してから一 定量のクロロホルムで再溶解する方法は難溶解性物質が 多く不適当であった。

炭酸ナトリウム層は希塩酸で酸性にし，クロロホルム で抽出した. 内部標準物質としてレブリン酸 2,4-DNPH を添加し，ジアゾメタンによりメチルェステル化し，ガ スクロマトグラフィーに注入した。ガスクロマトグラフ ィー条件は10\% Silicone SF-96 (担体 Chromosorb W) を用い,キャリャーガス $\mathrm{He}$, 注入部温度 $310^{\circ} \mathrm{C}$ ，カラム 温度 $240^{\circ} \mathrm{C}$ であた。

（3）比色法

i ) オキソ酸

ガスクロマトグラフィーによるオキソ酸の定量化は操 作手順が煩雑である。またガスクロマトグラフィーによ って本実験ではオキソ酸の大部分をピルビン酸が占める ことがわかった（グリオキシル酸の濃度は高い場合で も $(0.06 \mathrm{mg} / l)$ ので, 比色による方法も併用した。

炭酸ナトリウム層抽出液の一定量をとり, 蒸留水で全 容を $5 \mathrm{ml}$ 亿， $4 \mathrm{~N}$ 水酸化ナトリウム溶液 $2 \mathrm{ml}$ 加えて 発色させた。吸光度を波長440nm で測定し, 同じ操作で もとめた検量線からピルビン酸量をもとめた。

ii）ジカルボニル化合物

2,4-DNPH中性クロロホルム抽出液 $0.5 \mathrm{ml}$ に0. $25 \mathrm{~N}$ ア 62-

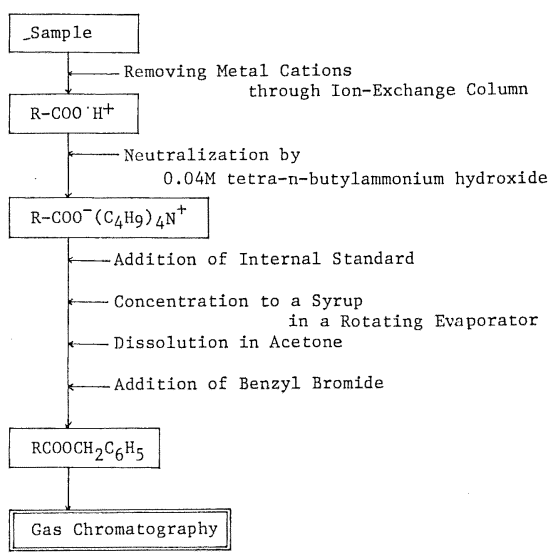

Fig. 3 Precedure for analysis of volatile fatty acids

ルコール性 $\mathrm{NaOH}$ 溶液 $5 \mathrm{ml}$ を添加した。共存する2,4DNP の退色が激しいので，一定時間に所定波長で吸光 度を測定した。

\section{5 低級脂肪酸}

Bethges ${ }^{5)}$ によって示された低級脂肪酸の測定法にも とづいた。Fig.3にそのフローを示す.

サンプル $50 \mathrm{ml} \mathrm{H}^{+}$型イオン交換樹脂 Dowex $50 \mathrm{~W}^{-}$ X8を通したのち，0.04M水酸化テトラーnーブチルアンモ ニウムで中和し, 内標準物質としてカプロン酸を添加 し, $40^{\circ} \mathrm{C}$ で減圧濃縮し水分を完全に取り除いた。残留物 であるテトラーnーブチルアンモニウム塩をアセトン溶か し，ベンジルブロミドを加觉、ベンジルェステル化して ガスクロマトグラフィーに注入した。この方法の検出限 界は0. $1 \mathrm{mg} / l$ である。本法は中和してできた塩やベン ジルエステル（b.p. 200C）は安定であるので, 蒸発や 分解によって試料を失うことにほとんどなく，回収率を 100\%近くあげることができる。しかし，サンプル量50

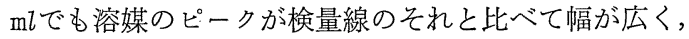
またテーリングを起しているのでサンプル量を増すこと によって検出限界を上げることは困難である。

ガスクロマトグラフィー条件はカラム充填剤 $3 \%$ Butane-1,4-diol succinate (担体 Chromosorb WAW DM (S)，キャリャーガス $\mathrm{He}$, 注入口湿度 $160^{\circ} \mathrm{C}$, 初期カラ 厶湿度 $120^{\circ} \mathrm{C} 15$ 分, 昇温 $2^{\circ} \mathrm{C} / \mathrm{min}$, 最終温度 $150^{\circ} \mathrm{C}$ であ った。

\section{3. 反応生成物の同定}

\subsection{2,4-DNPH}


Table 2 The color of 2,4-DNPH resulting from ozonation in secondary effluent

\begin{tabular}{c|l}
\hline \hline Reaction Time with Ozone & \multicolumn{1}{c}{ Color } \\
\hline 0 min & brown \\
1 & orange red \\
2 & orange red \\
5 & orange red \\
10 & orange red \\
20 & orange yellow \\
40 & orange yellow \\
60 & yellow \\
80 & yellow \\
\hline
\end{tabular}

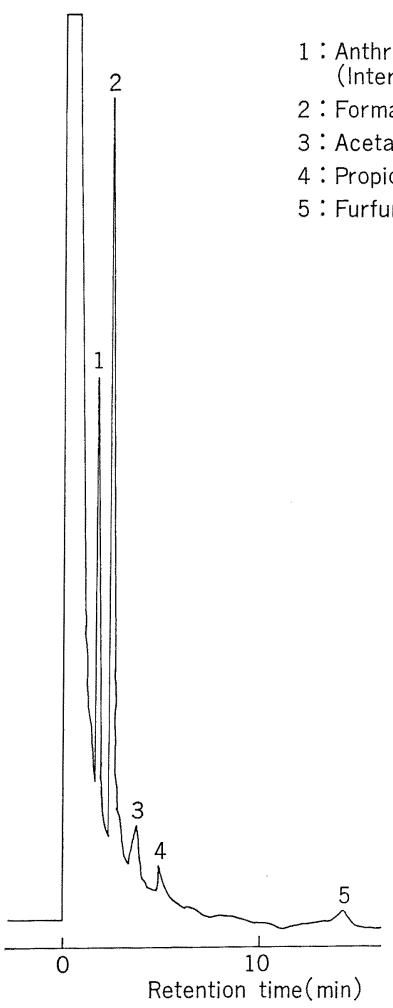

Fig. 4 Gas chromatogram of 2,4-DNPH of ozonated secondary effluent (ozone reaction time: 10 $\min$ )

2,4-DNPHは個々の物質で特有の色を呈する。オン゙ン 処理経時変化による2,4-DNPHの色の変化，拈よび代表 的カルボニル化合物の2,4-DNPH の色を Table 2, 3 は表わしている。オン゙ン処理時間の経過とともに2,4DNPHの色は茶色 $\rightarrow$ 赤橙色 $\rightarrow$ 黄橙色 $\rightarrow$ 黄色と変化し, 才 ゾン処理によってカルボニル化合物の組成が変化してい ることがわかる。
Table 3 The color of 2,4-DNPH

\begin{tabular}{|c|c|c|}
\hline Compounds & Color & $\begin{array}{l}0.25 \mathrm{~N} \text { Alcoholic } \\
\text { Color }\end{array}$ \\
\hline $\begin{array}{l}\text { formaldehyde } \\
\text { acetaldehyde } \\
\text { propionic aldehyde } \\
\text { furfural } \\
\text { glyoxal } \\
\text { methylglyoxal } \\
\text { diacetyl } \\
\text { glyoxylic acid } \\
\text { pyruvic acid }\end{array}$ & $\begin{array}{l}\text { yellow } \\
\text { yellow } \\
\text { orange yellow } \\
\text { deep red } \\
\text { orange red } \\
\text { orange red } \\
\text { orange red } \\
\text { yellow } \\
\text { yellow }\end{array}$ & $\begin{array}{l}\text { reddish brown } \\
\text { reddish brown } \\
\text { reddish brown } \\
\text { reddish brown } \\
\text { violet } \\
\text { purple } \\
\text { purple }\end{array}$ \\
\hline
\end{tabular}

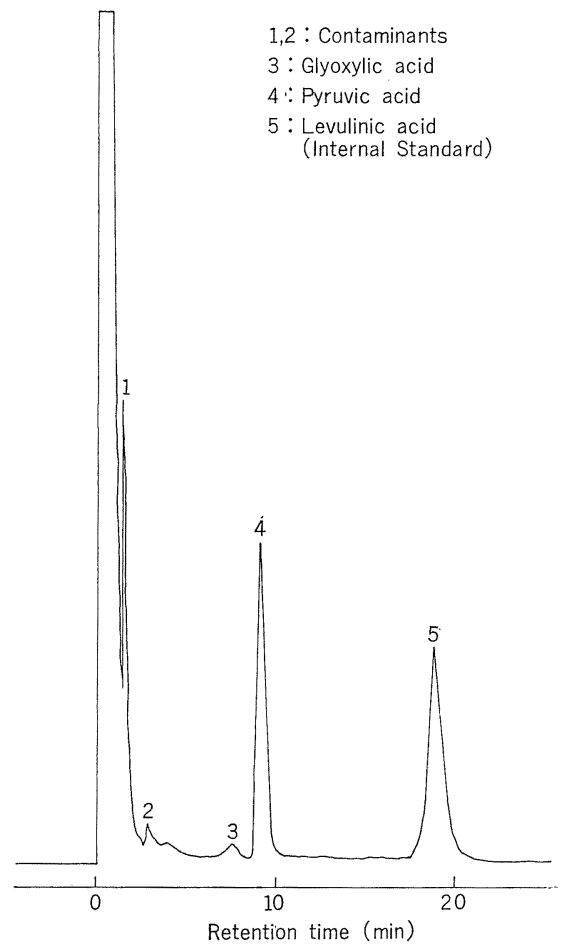

Fig. 5 Gas chromatogram of methylated compounds of 2,4-DNPH of oxo-acids from ozonated secondary effluent (ozone reaction time: 20 $\min$ )

\subsection{2,4-DNPH のガスクロマトグラフィー} オゾン処理10分の中性2,4-DNPHのガスクロマトグラ ムをFig. 4 亿示す。 4 個のピークが認められ，標準物質 と保持時間の関係より，ホルムアルデヒド，アセトアル デヒド，プロピオンアルデヒド，フルフラールを同定し た。このらち定量可能であったのはホルムアルデヒド で，同定できたモノアルデヒドの大部分をホルムアルデ ヒドが占めた。 


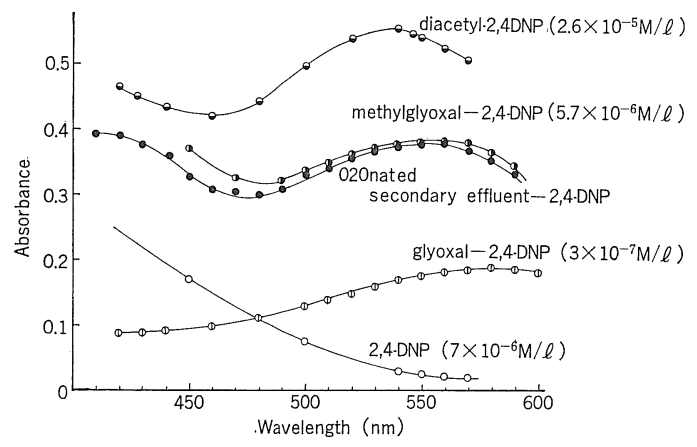

Fig. 6 Spectral Absorbtion of 2,4-DNPH

オゾン処理20分のアルカリ性2,4-DNPHのガスクロマ トグラムをFig. 5 に示す。グリオキシル酸, ピルビン酸 が同定でき，定量できるだけの高いピークを示したのは ピルビン酸だけであった。

\section{2 ジカルボニル化合物の存在の検討}

3.2 オゾン処理で主にホルムアルデヒド， ピルビン酸 が生成することがわかった。しかしこれらの 2,4-DNPH の色はTable 3 に示されるように沶の沶の黄色である。 ところがTable 2 で示されるらよにオゾン処理10分まで は2,4-DNPHは赤橙色を呈する。そこでジカルボニル化 合物の存在が推測され, オゾン処理水の中性 2,4-DNPH を0. $25 \mathrm{~N}$ アルコール性 $\mathrm{NaOH}$ 溶液としたところ, 深色 移動し, Fig. 6 に示すように波長約560nm で極大值を示 したジカルボニル化合物としてはグリオキザール，ビア セチル，メチルグリオキザールが考学られ，打の沶の

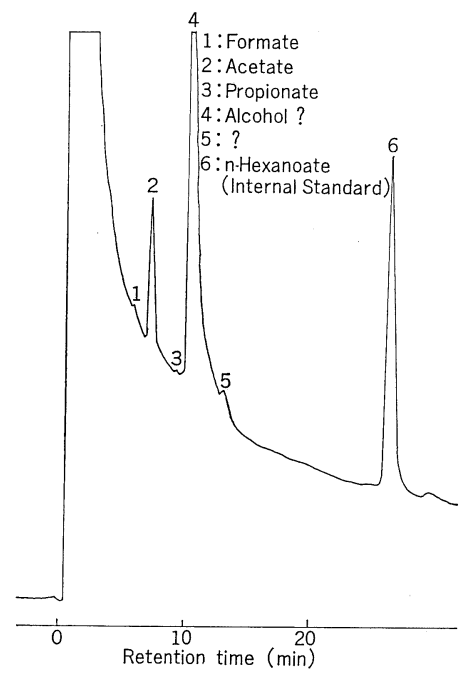

Fig. 7 Gas chromatogram of benzyl compounds of volatile fatty acids from ozonated secondary effluent (ozone reaction time: $80 \mathrm{~min}$ )
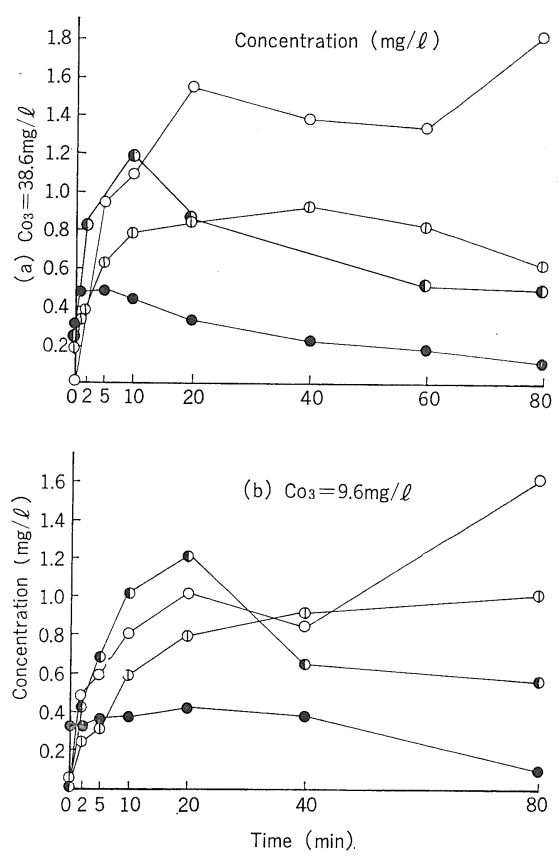

Fig. 9 Ozonation of Secondary effluent $\bigcirc$ : Acetic acid Methylglyozal () : Pyruvic acid Formaldehyde

2,4-DNPHの0.25Nのアルコール性溶液はそれぞれ波長 $575 \mathrm{~nm}, 540 \mathrm{~nm}, 560 \mathrm{~nm}$ で極大值を示した。オゾン処理 水の吸収スペクトルとメチルグリオキザールの吸収スペ クトルが同様な傾向を示すこと，グリオキザールの発色 はスミレ色でオゾン処理水，ビアセチル，メチルグリオ キザールのそれは紫色であること，ビアセチルについて は Westerfeld ${ }^{6)}$ にる方法で同定を行ないオゾン処理水 のジカルボニル化合物がビアセチルでないことを確認し たこと，等から，ジカルボニル化合物2,4-DNPHのほと んどがメチルグリオキザールであることを推定した。

\section{4 低級脂肪酸のガスクロマトグラフィー}

オゾン処理 80 分の低級脂肪酸のガスクロマトグラムを Fig. 7 に示す。ギ酸, 酢酸, プロピオ酸が同定できた が，定量できるだけの量が存在したのは酢酸だけであっ た。

\section{4. 反応生成物の挙動}

定量化できた 4 物質, ホルムアルデヒド，メチルグリ オキザール，ピルビン酸，酢酸についてその挙動を考察 する。

\section{1 経 時 変 化}


これら 4 物質の濃度の経時変化を送入オゾン濃度 38.6 $\mathrm{mg} /$ lの場合を例にとってFig. 8 (a) 亿示す。ただしオゾ ンによる各物質の生成と分解は同時飞起っていると考克 られるので，これらの図が示す各物質の濃度の增減は真 の生成と分解を表わすのではなく，又かけの生成と分解 を表わしている。

反応生成物の增減パターンは各物質で特徴的である。 ホルムアルデヒドは反応初期 1 〜 分でピークを生じ, 以後ゆるやかに減少する。ホルムアルデヒドがオゾンに より酸化されるとすれば酸が生成されるのに，ギ酸が注 とんど存在しないことから，ホルムアルデヒドは見かけ 上, 二酸化炭素と水になる ${ }^{3)}$ と思わ枦。ホルムアルデ ヒドのピーク值は $0.48 \mathrm{mg} / l$ であった。

メチルグリオキザールはホルムアデヒドと似た傾向を 示すが，増加する期間がやや長い。10分で $1.2 \mathrm{mg} /$ ののピ 一ク值を示し, 以後減少している。オン゙ンにより生成も するが比較分解もされやすい。

ピルビン酸はゆるやかに增加し，20分から40分程度で ピークを迎光，60分，80分と活とんど変化しないか，あ るいは場合によって徐々に減少するピーク值は $0.90 \mathrm{mg}$ $/ l$ 程度である。

酢酸は20分で増加し，40分，60分では変化がないか， 減少かを示し, その後80分では再び増加している。20分 で1. $56 \mathrm{mg} / l, 80$ 分で $1.80 \mathrm{mg} / l$ となっている。

メチルグリオキザール，ピルビン酸, 酶酸の間には深 い関連があり，次にあげる(1)式の上らな反応が考兄ら れる。

$$
\begin{aligned}
& +0 \quad+0 \\
& \mathrm{CH}_{3} \mathrm{COCHO} \rightarrow \mathrm{CH}_{3} \mathrm{COCOOH} \rightarrow \mathrm{CH}_{3} \mathrm{COOH}+\mathrm{CO}_{2} \\
& \text { 反応 I 反応 } I
\end{aligned}
$$

10〜20分のメチルグリオキザールの滅少期にはピルビン 酸量が増加，またはプラトー状であることから反応 I が 起っていることが推察できる。反応IIは60〜80分のピル ビン酸の減少に伴って酶酸の再度の増加があることから 理解できる。処理開始から20分間では酢酸の増加がピル ビン酸の增加に比べて大きいのは，早い速度で反応 I, IIが起っているか，高分子の開裂など別の経路から酢酸 の生成が起っていると考光られる。

\section{2 送入オソン濃度の影響}

送入オゾン濃度 $9.6 \mathrm{mg} / l$ である実験の反応生成物の濃 度の経時変化をFig. 8 (b) 亿示す。

ホルムアルデヒドは明確なピークを示さず20分まで増 加し, 以後徐々に減少している。ピルビン酸は80分まで 増加を続け, メチルグリオキザールの減少はFig.(a) そ
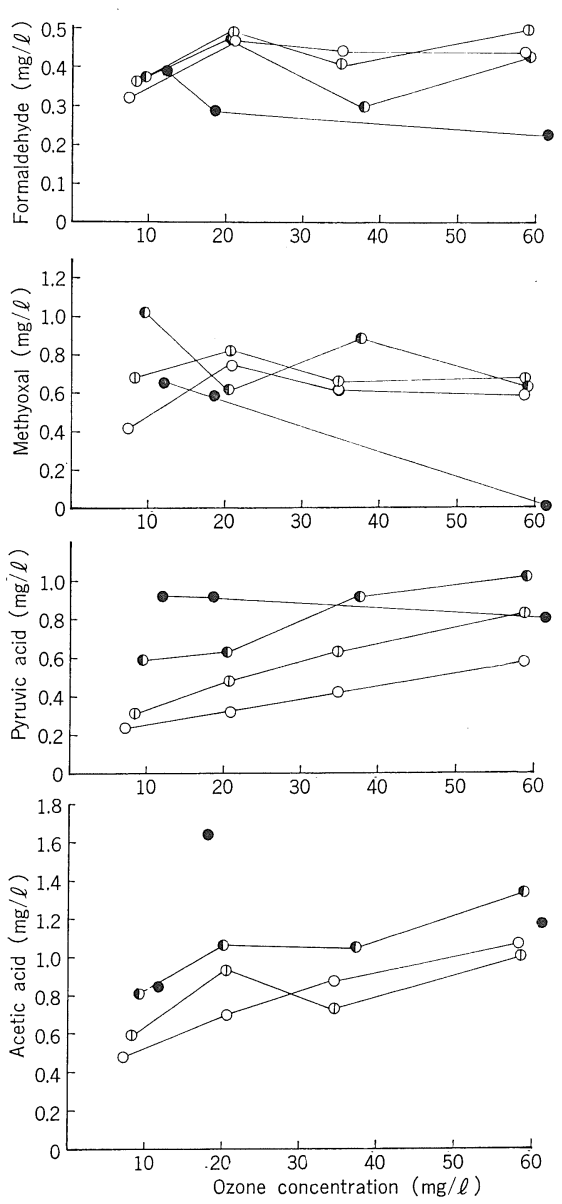

Fig. 9 Effect of ozone concentration reaction time $0: 2 \mathrm{~min} \quad(\mid): 5 \mathrm{~min} \quad$ (1): $10 \mathrm{~min} \quad 0: 40 \mathrm{~min}$ れに比べて少ない。これらのことはオゾン濃度が低いの で分解まで反応がすみやかに進まないためと思われる。 送入オゾン濃度9.6 59. $5 \mathrm{mg} /$ / の間で, 送入オゾン濃度 とホルムアルデヒド，メチルグリオキザール，ピルビン 酸, 酢酸それぞれの濃度との関係を示したのがFig. 9 で ある。

ホルムアルデヒドのみかけ上の生成は送入オゾン濃度 にあまり関係なく $0.4 \sim 0.5 \mathrm{mg} / l$ であった。これはオン゙ ン高濃度でホルムアルデヒドが実際多量に生成されても すみやかに分解され，結果として低濃度で存在し，また オゾン低濃度ではホルムアルデヒドが生成されても分解 が遅いため比較的長時間処理中に存在することによる。

メチルグリオキザールに関しては，送入オゾン濃度低 濃度の場合を除いて，接触時間10分まではオゾン濃度に よる差があまりなく，この期間内に $0.6 \sim 0.9 \mathrm{mg} / l$ のピ 一ク值を示し, 接触時間40分になると送入オゾン濃度が 高くなるにつれて，メチルグリオキザール濃度が低くな 
っておりりオゾン濃度が高い法どよく分解されることが わかる。

ピルビン酸は，その濃度が接触時間分までは送入オゾ ン濃度の増大とともに増加し，みかけの生成量が高まっ て扣り, 送入オゾン濃度とみかけの生成量は比例関係に ある。接触時間40分になると送入オゾン濃度が高い場合 は減少がみられ，分解量の方が多くなっている。Fig. 8 でみられるよらに, 送入オゾン濃度約 $40 \mathrm{mg} / l$ ではピル ビン酸濃度は40分まで増加し，60，80分でみかけの分解 がみられる。

酢酸はピルビン酸の場合と同様，接触時間10分までは 送入オゾン濃度の増大とともに酢酸濃度も増加してい る。接触時間40分では濃度值がばんつくが，これに送入 オン゙ン濃度が高いものは酢酸濃度の経時変化パターンで 減少の傾向を示す時期であるからであろらと思われる。

Fig. 8 の0，60分での減少はこの時期に酢酸の分解速度 が生成速度を上回ることを示している。

\subsection{2,4-DNPH 量の経時変化}

科量法による 2,4-DNPH 量の経時変化を Fig.10 に示
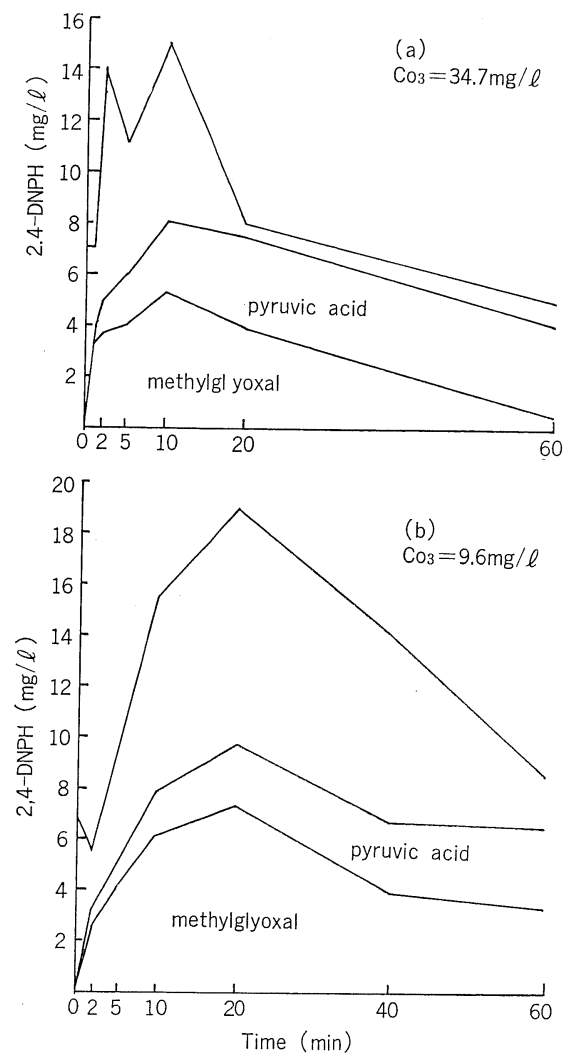

Fig. 10 2,4-DNPH products from ozonation of secondary effluent
す。また比色法により測定されたピルビン酸量, メチル グリオキザール量を2,4-DNPH量に換算してともにあら わしている。ホルムアルデヒド2,4-DNPHは本実験のよ らな低濃度ではろ紙を通過しろ液中に存在することを GC法で確認したのでこには表わしていない。Fig.11(a) より，2,4-DNPH量は反応時間 $2 \sim 10$ 分ピークとなり， 20分以降の減少期にはピルビン酸とメチルグリオキザー ルで80へ90\%を占めていること, 特に60分ではピルビン 酸が卓越していること，等がわかる。この事実はTable 2 で示される2,4-DNPHの色が，反応初期の赤橙色は一 部はメチルグリオキザールで，反応時間60分，80分の黄 色はピルビン酸であることを裏付けている。反応初期 10 分については，本研究で同定されなかった物質が存在し ていることを示している。Fig.(b) は送入オン゙ン濃度が 低い場合である。低濃度の場合カルボニル化合物は比較 的ゆっくり生成し処理水中に長時間存在することがうか がわれる。しかも処理時間40分までピルビン酸, メチル グリオキザール以外のカルボニル化合物が比較的多いこ とがわかる。

\section{$4.4 \mathrm{COD}(\mathrm{Cr})$ との関連について}

ホルムアルデヒド，メチルグリオキザール（ピルビン 酸, 酢酸について理論的酸素要求量を求め, 各反応時間 ごとに $\mathrm{COD}_{(\mathrm{Cr})}$ に対する比率をあらわした 1 例がFig.11

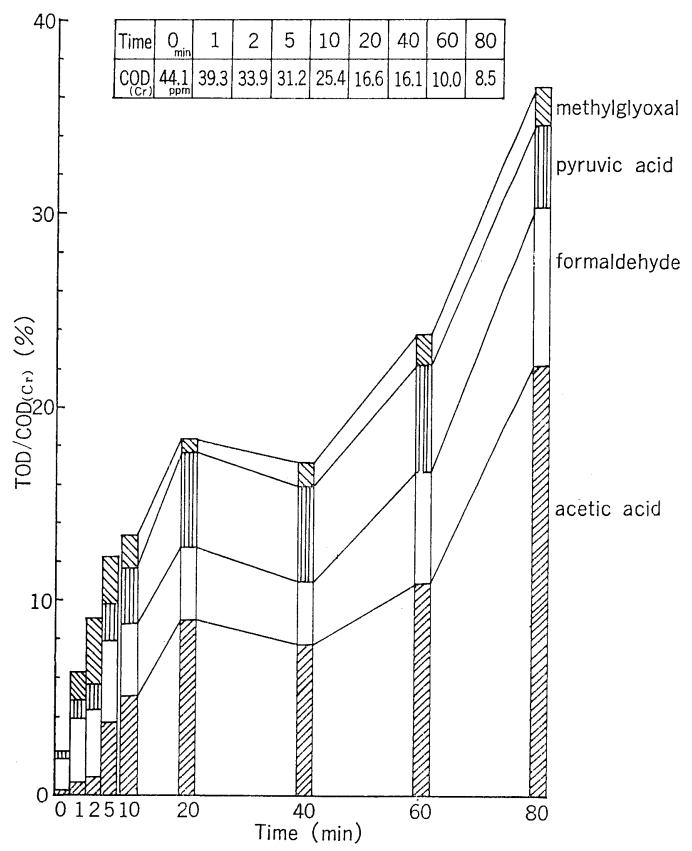

Fig. 11 The ratio of TOD summation on determined organic compounds to total $\mathrm{COD}_{(\mathrm{Cr})}$ 
である。この 4 物質の合計で， 5 分で12\%，10分で14\% 20分で18\%，60 分で $24 \% ， 80$ 分で 36\% 程度を占めてい る。ホルムアルデヒドとメチルグリオキザールについて は, 3 回の同様な実験によってそれぞれ $\mathrm{COD}_{(\mathrm{Cr})}$ に対す る割合が異なって和り，初期水質の影響かと思われる。 ピルビン酸と酢酸は 3 実験とも近い值で, ピルビン酸は 5 分：2\%, 10分：3\%, 20分：4\%, 40分：5\%,60分: 6\%，80：4.5分\%であり，酢酸は5分：3\%，10分： $4 \%, 20$ 分: $7 \%, 40$ 分：8\%，60分：10\%，80分：攻 \%である。本研究で㤋析操作上落酸を同定することが できなかったが，80分処理すると残存する $\mathrm{COD}_{(\mathrm{Cr})} 8.5$ ppm中の $20 \%$ 近くを酶酸が占めているわけで, 酶酸は通 常のオゾン酸化過程の最終生成物の一つであるとい光 る。

\section{5. ま とめ}

2, 4-DNHPによるカルボニル化合物, 拉よびベンジル エステル化によるカルボン酸の定量法を用い， 2 次処理 水のオゾン処理生成物について検討を行なったところ, 次のようなことが明らかになった。

（1）カルボニル化合物, 扣よび低級脂肪酸のらち, 次 の物質を同定した。

ホルムアルデヒド, アセトアルデヒド, プロピオンア ルデヒド，フルフラール，メチルグリオキザール，グリ オキシル酸，ピルビン酸，ノギ酸，酢酸，プロピオン 酸。

(2) 同定できた物質のうち卓越してくる種類は一定し て㐨り, ホルムアルデヒド, ピルビン酸, メチルグリオ キザール, 酢酸であり, $0 \sim 2 \mathrm{mg} / \mathrm{l}$ のオーダーで存在 した。この 4 物質の生成特性は以下のようであった。

(3) ホルムアルデヒド, メチルグリオキザールはオゾ ンにより生成されても分解も容易で，特にホルムアルデ ヒドは分解が速く, 送入オゾン濃度によるその違いはあ まりなかった。

（4）ピルビン酸, 酸酸はオゾン処理により生成され, 徐々に濃度の高まるオゾンによる分解の比較的遅い物質 であった。酢酸はオゾン処理による最終生成物の一つと して考兄られた。

以上, オゾン処理のオン゙ン濃度, 処理時間による生成 物の特性を一部明らかにできた。しかしまだまだ不明 な点は多い。今後, 分析技術の発展により反応生成物に ついてのさらに詳細な研究がなされ, オン゙ン処理の安全 性が確認されることが望をれる。

（原稿受理：昭和54年 4 月21日）

\section{一引用文献一}

1) Joseph, P.G. and Walter J, W.Jr. (1976) Oxidation of phenols by ozone. Journal WPCF, 28(1), 4760

2) Powell, P.K.KuO, Edward, S.K. Chian and Bei.I. Chang (1977) Identification of end products resulting from ozonation and chlorination of organic compounds commonly found in water. Environmental Science \& Technology, 11(13), 1177-1181

3）山田春美, 宗宮 功, (1978)オゾン処理に括けるホ ルムアルデヒドの生成拉よび分解, 土木学会第33回 年次学術講演会講演概要集, 第 II 部, 163-164

4) 清水康夫, 松任茂樹, 伊東保之, 岡田郁之助 (1969) カルボニル化合物の 2,4-dinitrophenylhydrazone の 直接ガスクロマトグラフィー, 農化，43(4)，211216

5）船久保英一（1975）有機化合物確認法 I, p.379, 養 賢堂

6）清水康夫, 松任茂樹, 水沼保之, 岡田郁之助(1970) でんぷんの焙焼香気に関する研究（第 1 報）でんぷ んの焙焼香気成分の捕集分画ならびにカルボニル化 合物の単離同定, 日本食品工業学会誌, 17(9), 385 $-390$

7) Bethge, P.O., Lindström, K. (1974) Determination of organic acids of low relative molecular mass $\left(\mathrm{C}_{1}\right.$ to $\left.\mathrm{C}_{4}\right)$ in dilute Aqueous Solution. Analyst, 99, $137-142$

8) Westerteld, W.W. (1945) A colorimetric determination of blood acetoin. J. Biol. Chem,. 161, 495 $-502$ 